\title{
Gene duplication and functional divergence of the zebrafish insulin-like growth factor 1 receptors
}

\author{
Peter J. Schlueter,* Tricia Royer,* Mohamed H. Farah,* Benjamin Laser,* \\ Shu Jin Chan, ${ }^{\dagger}$ Donald F. Steiner, ${ }^{\dagger}$ and Cunming Duan*,1 \\ *Department of Molecular, Cellular, and Developmental Biology, University of Michigan, Ann Arbor, \\ Michigan, USA; and ${ }^{\dagger}$ Howard Hughes Medical Institute, University of Chicago, Chicago, Illinois, USA
}

To read the full text of this article, go to http://www.fasebj.org/cgi/doi/10.1096/fj.05-3882fje

\section{SPECIFIC AIMS}

RECENT STUDIES HAVE shown that zebrafish have two distinct insulin-like growth factor type 1 receptor (IGF1R) genes, igflra and igflrb; however, their relationship and their functions are unknown. The aim of this study was to test the hypothesis that zebrafish igflra and igf1rb resulted from a gene duplication event that led to their functional divergence.

\section{PRINCIPAL FINDINGS}

1. Genomic structure and chromosomal locations of zebrafish igflra and igflrb

The zebrafish igflra spans $151.5 \mathrm{~kb}$ in the genome and has 21 exons. The zebrafish igflrb spans $156.5 \mathrm{~kb}$ and has 22 exons. Comparisons of exon number and length of the two zebrafish genes with those of the human $I G F 1 R$ gene indicated a high degree of cross-species conservation. igflra is located on zebrafish linkage group (LG) 18, while $i g f 1 r b$ is located on LG 7. Further analysis suggested that igflrb and six other zebrafish genes located on LG 7 have orthologs on human chromosome 15. Similarly, igflra and four other zebrafish genes located on LG 18 also have orthologs on human chromosome 15. Therefore, the two zebrafish $i g f 1 r$ are encoded by distinct genetic loci believed to evolve from a common ancestral IGF1R locus, and there is strong syntenic correspondence between the two zebrafish igflr genes and the human IGF1R gene.

\section{Both igflra and igflrb are required for proper zebrafish embryonic growth, development, and survival}

To elucidate the functional relationship between igflra and igflrb, we knocked down each individually or in combination using an antisense MO-based targeted gene knockdown approach. Two distinct antisense MOs were designed for each target gene, and their efficacy and specificity in targeting their respective igflr gene product were validated. Two gene-specific mis-sense MOs were used as controls. Knockdown of igflra or $i g f 1 r b$ resulted in embryos that were smaller and more developmentally delayed than control MO-injected embryos (Fig. 1A). These embryos survived to $48 \mathrm{hpf}$, and $\sim 50 \%$ were alive at $72 \mathrm{hpf}$ but none beyond $96 \mathrm{hpf}$. At $24 \mathrm{hpf}$, the mean body length and somite number of igflra and igflrb MO-injected embryos were significantly reduced (Fig. $1 B, C$ ). When both igflra and igflrb were knocked down by injecting a combination of all four targeting igflr MOs, all embryos died by 30 hpf. At 24 hpf, their body size and developmental rate (somite number) were significantly smaller than those of the single knockdown group (Fig. 1B, C), suggesting the two genes play similar and likely additive roles in regulating embryonic growth, developmental rate, and survival.

\section{Overlapping functions of igflra and igflrb in regulating embryonic tissue growth and differentiation}

To determine the roles of igflra and igflrb in organogenesis, we analyzed the impact of knocking down igflra or igflrb on eye, inner ear, and heart formation and differentiation. Knockdown of either igflra or $i g f 1 r b$ caused similar reductions in the expression levels of $r x 1 \mathrm{mRNA}$, a retina-specific homoebox gene. There was also a similar absence of differentiated retinal ganglion cells in the retina and sensory hair cells in the otic vesicles in igflra and igflrb MO-injected embryos. Knockdown of igflra or igflrb individually also caused a similar degree of delay in the timing of heart morphogenesis and reduction of differentiated cardiac tissue. These results indicated that igflra and igflrb play largely similar roles in eye, inner ear, and heart development.

\footnotetext{
${ }^{1}$ Correspondence: Department of MCDB, University of Michigan, Kraus Natural Science Bldg., Ann Arbor, MI 48109, USA. E-mail: cduan@umich.edu doi: 10.1096/fj.05-3882fje
} 

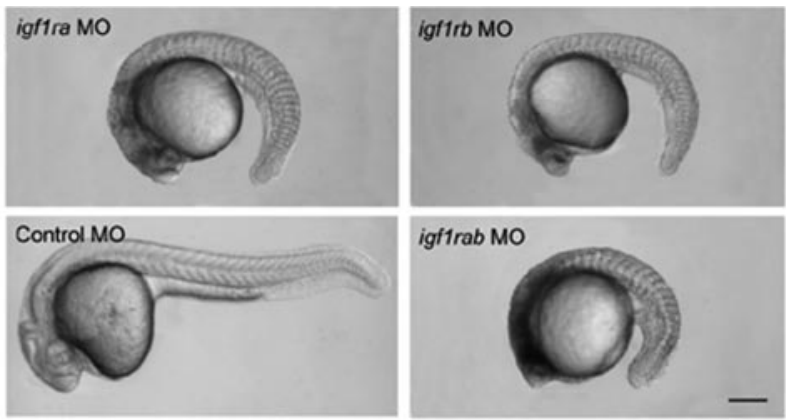

B

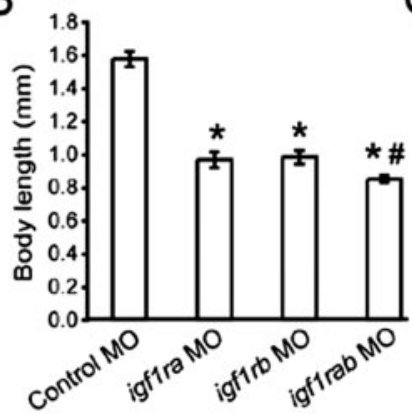

C

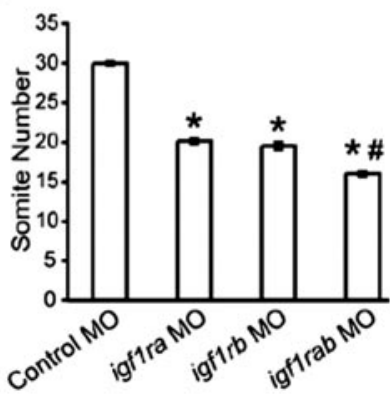

Figure 1. Zebrafish igflra and igflrb play overlapping but nonredundant roles in regulating growth and developmental rate. A) Morphology of $24 \mathrm{hpf}$ embryos injected with igf1ra MOs, igf1rb MOs, igf1ra MOs + igf1rb MOs (igf1rab MO), or control MOs. Scale bar $=250 \mu \mathrm{m}$. B) Body length and $C$ ) somite number of embryos shown in panel $A$. Results are from 3 independent experiments, each with 15 embryos per group. $* P<0.0001$ compared with the control MO-injected group, and $\# P<0.001$ compared with that of the igflra or igflrb MO-injected group.

\section{Igf1rb plays a greater role in spontaneous muscle contractility and motoneuron development}

During the course of the study, we noticed a marked difference in spontaneous contractile activity among the experimental groups. Wild-type zebrafish embryos spontaneously contract their tail muscles at $24 \mathrm{hpf}$ as their motoneuron axons innervate the somitic myotome. By $48 \mathrm{hpf}$, this spontaneous contractility ceases and embryos exhibit rhythmic bouts of swimming. Control MO-injected embryos were indistinguishable from their wild-type siblings, $100 \%$ exhibiting spontaneous muscle contractions at $24 \mathrm{hpf}$ and $0 \%$ at $48 \mathrm{hpf}$ (Fig. 2A). In the igflra MO-injected group, $69.0 \pm$ $3.07 \%$ of the embryos at $24 \mathrm{hpf}$ and $91.5 \pm 0.54 \%$ at 48 hpf displayed spontaneous contractility, indicating that depletion of igflra delayed the timing of this behavior. In contrast, few of the igflrb MO-injected embryos exhibited spontaneous muscle contractility at either 24 hpf $(8.65 \pm 0.60 \%)$ or $48 \mathrm{hpf}(5.5 \pm 0.75 \%)$, suggesting that depletion of igflrb either abolished this behavior or caused a greater delay.

The lack of spontaneous muscle contractility would imply defects in muscle differentiation, motoneuron innervation, or both. Whole mount in situ hybridization analysis showed that both igflra and igflrb MO-injected embryos exhibited robust mRNA expression of myoD (Fig. 2B, upper panels) and myogenin (data not shown) at $24 \mathrm{hpf}$, indicating normal somitogenesis. F59 staining of fast and slow muscle indicated that knockdown of either igflra or igflrb caused a reduction in muscle differentiation and the degree of reduction was comparable (Fig. 2B, middle panels). Therefore, although muscle differentiation was impaired, it is not likely the underlying cause of the difference observed in spontaneous muscle contractility. These results led us to hypothesize alternately that $i g f 1 r b$ may play a greater or more specific role in promoting motoneuron differentiation. This idea was tested by staining embryos with an antibody against SV2, which labels motoneurons and their axons. As shown in Fig. 2B, axons from the caudal primary motoneurons (CaP) of control MO-injected
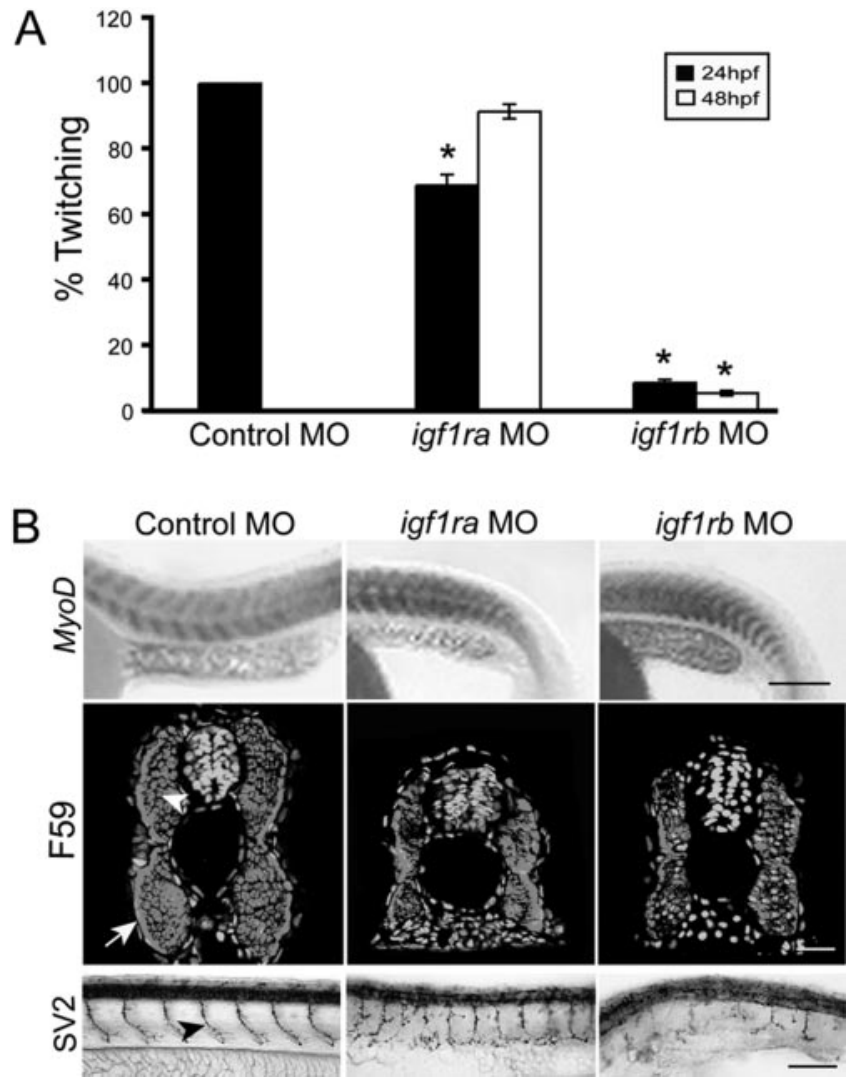

Figure 2. Igflrb plays a greater role in regulating spontaneous muscle contractility and motoneuron differentiation. A) Percent of embryos exhibiting spontaneous muscle contractility at 24 (filled bar) or $48 \mathrm{hpf}$ (open bar) in the control, igflra, or igf1rb MO-injected group. Results were obtained from 3 independent microinjection experiments, with 45 embryos per group. $* P<0.0001$. B) Expression pattern of myoD mRNA in 24 hpf control, igflra, or igflrb MO-injected embryos (upper panel). Scale bar $=250 \mu \mathrm{m}$. Slow and fast muscle muscles (labeled by F59 staining, red) in $48 \mathrm{hpf}$ control, igf1ra, or igf1rb MO-injected embryos (middle panel). The sections were counterstained with sytox (green, nuclear staining). Scale bar $=20 \mu \mathrm{m}$. CaP motoneuron axons (labeled by SV2 staining, dark) in $48 \mathrm{hpf}$ control, igf1ra, and igflrb MO-injected embryos (bottom panel). Scale bar $=100$ $\mu \mathrm{m}$. Lateral views are shown with anterior to the left and dorsal up. 


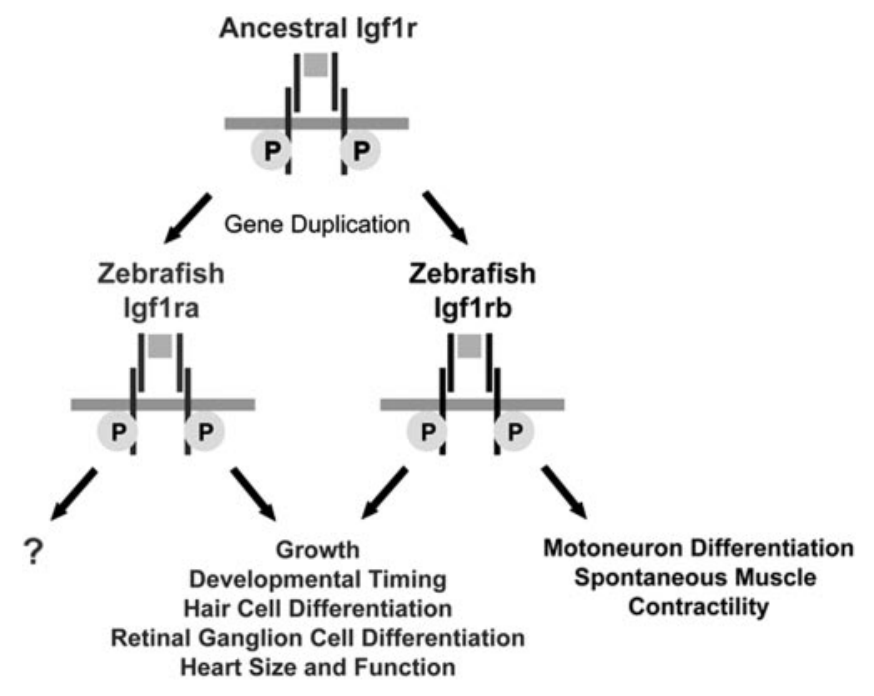

Figure 3. A schematic diagram illustrating the duplication and subsequent functional diversification of zebrafish igflra and igflrb.

embryos clearly innervated the muscle and were well organized; however, CaP axons in igflra and igflrb MO-injected embryos were significantly impaired, but the effect was more pronounced in the igflrb MOinjected embryos. The igfirb MO-injected embryos had $4.5 \pm 0.46 \mathrm{CaP}$ axons, significantly less than the $8.4 \pm$ 0.8 axons in igflra MO-injected embryos, and the $9.0 \pm$ 0.0 axons in control MO-injected embryos $(p<$ $0.0001)$. These data suggest that while both Igflra and Igflrb are important for muscle differentiation, Igflrb plays a greater or more specific role in promoting motoneuron innervation.

\section{CONCLUSIONS AND SIGNIFICANCE}

In this study we provide evidence that zebrafish Igflra and Igflrb are encoded by two distinct genetic loci believed to have evolved from a common ancestral locus. Additionally, we show a strong syntenic correspondence between the two zebrafish igflr genes and the human IGF1R gene, suggesting that zebrafish igflra and igflrb likely originated from a gene duplication event that occurred during teleost evolution. This conclusion is consistent with the notion that zebrafish and other fishes in the killifish lineage may have experienced an additional gene duplication event during evolution, a theory derived from studies of the Hox gene family in zebrafish and Fugu.

Gene duplication is thought to be the primary source of new genes. Permanent preservation of both duplicates requires divergent functions, but deci- phering whether a pair of duplicated genes has evolved divergent functions is often challenging. In this study, we explored the power of the zebrafish model and determined the functional relationship of the duplicated zebrafish igflr genes. Knockdown of zebrafish igflra and igflrb together resulted in 100\% lethality by $30 \mathrm{hpf}$. These embryos were significantly smaller, about half that of their wild-type siblings, and exhibited significantly reduced somite number, suggesting developmental delay. These phenotypes are consistent with those reported in human patients and $I g f 1 r$ null mice. When a single igflr, either igflra or igflrb was knocked down, the embryos could survive beyond $48 \mathrm{hpf}$, but with greatly increased mortality rates thereafter. Knockdown of igflra or $i g f 1 r b$ individually resulted in similar reductions in body size, development rate, differentiated RGCs, sensory hair cells in the inner ear, and skeletal muscle. Heart development and growth were also impaired in these embryos. These results suggest that the duplicated zebrafish igflr genes play largely similar roles in zebrafish development.

Despite these apparent overlapping functions, igf1ra and igflrb are not strictly redundant but appear to play additive roles, because embryos lacking both receptors are more severely growth and developmentally retarded than embryos lacking either receptor alone. While knockdown of either igflrb or igflra caused a comparable reduction in muscle differentiation, knockdown of igflrb, but not igflra, caused a failure of embryos to exhibit spontaneous muscle contractility. Further analysis indicated that Igflrb plays a greater or more specific role in promoting motoneuron innervation of the myotome. The mechanism underlying the functional differences in spontaneous muscle contractility and motoneuron differentiation between zebrafish Igfl ra and Igf1rb is not yet clear. Differences in ligand binding affinities, gene expression patterns, and/or signal transduction mechanisms may account for the functional specificity of the two zebrafish $i g f 1 r$ genes. The two zebrafish Igflrs are only $70 \%$ identical to each other, with the divergent residues spread throughout the molecules, and there are significant differences in their cytoplasmic regions. It is possible that these divergent sequences may confer different signaling capacities between the two receptors. Further studies focusing on determining whether the duplicated zebrafish Igf1rs possess similar or different cellular distribution patterns and/or signaling properties will be needed to elucidate the molecular mechanisms underlying their functions. 


\title{
Gene duplication and functional divergence of the zebrafish insulin-like growth factor 1 receptors
}

\author{
Peter J. Schlueter ${ }^{1}$, Tricia Royer ${ }^{1}$, Mohamed H. Farah ${ }^{1}$, Benjamin Laser ${ }^{1}$, \\ Shu Jin Chan ${ }^{2}$, Donald F. Steiner ${ }^{2}$, and Cunming Duan ${ }^{1}$ \\ Department of Molecular, Cellular, and Developmental Biology, University of Michigan, Ann Arbor, \\ MI 48109; and Howard Hughes Medical Institute, University of Chicago, Chicago, IL 60637
}

ABSTRACT Insulin-like growth factor (IGF) 1 receptor (IGF1R)-mediated signaling plays key roles in growth, development, and physiology. Recent studies have shown that there are two distinct igflr genes in zebrafish, termed igf1ra and igflrb. In this study, we tested the hypothesis that zebrafish igf1ra and igflrb resulted from a gene duplication event at the igflr locus and that this has led to their functional divergence. The genomic structures of zebrafish igflra and igflrb were determined and their loci mapped. While zebrafish igflra has 21 exons and is located on linkage group (LG) 18, zebrafish igflrb has 22 exons and mapped to LG 7. There is a strong syntenic relationship between the two zebrafish genes and the human IG F1R gene. Using a MO-based loss-of-function approach, we show that both Igf1ra and Igf1rb are required for zebrafish embryo viability and proper growth and development. Although Igf1ra and Igf1rb demonstrated a large degree of functional overlap with regard to cell differentiation in the developing eye, inner ear, heart, and muscle, they also exhibited functional distinction involving a greater requirement for Igf1rb in spontaneous muscle contractility. These findings suggest that the duplicated zebrafish igflr genes play largely overlapping but not identical functional roles in early development and provide novel insight into the functional evolution of the IGF1R/insulin receptor gene family.Schlueter, P. J., Royer, T., Mohamed, H. F., Laser, B., Chan, S. J., Steiner, D. F., Duan, C. Gene duplication and functional divergence of the zebrafish insulin-like growth factor 1 receptors. FASEB J. 20, E462-E471 (2006)

Key Words: IGF signaling $\cdot$ growth $\cdot$ developmental timing - retina $\cdot$ inner ear $\cdot$ heart $\cdot$ muscle

THE TYPE- 1 IGF receptor (IGF1R), which binds to and is activated by IGF1 or IGF2, plays key roles in human growth, development, and physiology (1-3). The human IGF1 $\mathrm{R}$ is a heterotetrameric transmembrane protein, consisting of two $\alpha$ and two $\beta$ subunits, linked by disulfide bonds (4). Ligand binding induces IGF1R autophosphorylation at tyrosine residues, activating multiple downstream signal transduction cascades, including the mitogen-activated protein kinase (MAPK) pathway and phosphoinositide-3-kinase (PI3K)-Akt pathway $(1,2)$. Patients with point mutations in the IGF1R gene exhibited severe intrauterine growth restriction and poor postnatal growth $(5,6)$. Likewise, loss-of-function mutations in the human IGF1 gene resulted in severe fetal and postnatal growth failure, and in mental retardation and sensorineural deafness (7-9).

The central role of IGF1R-mediated signaling in growth or size control has been demonstrated by mouse genetic studies. Homozygous $I g f 1 r$ null mutant mice exhibited severe but proportional growth retardation (45\% of the wild type littermates) and neonatal lethality $(10,11)$. Although $\operatorname{Ig} f 1 r$ knockout mice exhibited decreased numbers of specific neurons and reduced myelination, there was no evidence of major organ loss or patterning abnormalities $(10,11)$. Therefore, the IGF1R-mediated signaling is believed to be a key growth regulator in development $(12,13)$. Recent studies in Xenopus suggested that IGF1R-mediated signaling is important for anterior neural induction (14-16); similarly, a study using zebrafish reported that overexpression of a similar dominant negative IGF1R construct caused defects in head and central nervous system development (17).

Recently we have shown that there are two distinct $i g f 1 r$ genes in zebrafish, termed igflra and igflrb, and that they are expressed in overlapping spatial domains throughout embryogenesis (18). Like the human IGF1R, both zebrafish Igflra and Igf1rb are heterotetrameric transmembrane proteins, consisting of two $\alpha$ and two $\beta$ subunits, and they bind to IGFs but not to insulin. The relationship between the two zebrafish $i g f 1 r$ genes, however, is not clear and their functions are unknown. In this study, we tested the hypothesis that igflra and igflrb originated from a gene duplication event, which led to their functional divergence. Our results suggest that zebrafish igflra and ig flrb are encoded by distinct genetic loci believed to evolve from a common ancestral gene, and there is strong syntenic correspondence between zebrafish igflra and igflrb

\footnotetext{
${ }^{1}$ Correspondence: Department of MCDB, University of Michigan, Kraus Natural Science Bldg., Ann Arbor, MI 48109, USA. E-mail: cduan@umich.edu doi: 10.1096/fj.05-3882fje
} 
and the human IGF1R gene. Employing a MO-based targeted gene knockdown approach, we provide evidence that igflra and igflrb play largely overlapping, but not identical roles in zebrafish development.

\section{MATERIALS AND METHODS}

\section{Materials}

All chemicals and reagents were purchased from Fisher Scientific (Pittsburgh, PA) unless otherwise noted. RNase-free DNase was purchased from Promega (Madison, WI). Restriction endonucleases were purchased from New England BioLabs (Beverly, MA). PCR primers were synthesized by Invitrogen Life Technologies, Inc. (Carlsbad, CA). Akt antibodies were purchased from Cell Signaling (Beverly, MA), the antiTubulin antibody (Ab) was purchased from Sigma (St. Louis, $\mathrm{MO}$ ), and the SV2 and Zn5 monoclonal antibodies were purchased from the Developmental Studies Hybridoma Bank (University of Iowa). The LN54 radiation hybrid panel was kindly provided by Dr. M. Ekker, and the F59 Ab by Dr. F. Stockdale. Plasmid DNAs for making various riboprobes were generously provided by Drs. R. Kollmar (claudin- $a$ ), S. Lyons (nkx2.5), P. Raymond (rx1, rx2) and S.J. Du (myoD, myogenin).

\section{Experimental animals}

Adult wild-type (WT) zebrafish (Danio rerio) were maintained at $28 \mathrm{C}$ on a $14 \mathrm{~h}: 10 \mathrm{~h}$ (light: dark) cycle, and fed twice daily. Embryos were generated from natural crosses. Fertilized eggs were raised in embryo medium at $28.5^{\circ} \mathrm{C}$ and staged according to Kimmel et al. (19). All experiments were conducted in accordance with guidelines approved by the University Committee on the Use and Care of Animals, University of Michigan.

\section{Determining the structure and physical mapping of zebrafish igf1ra and igf1rb}

The zebrafish igflra and igflrb genomic structures were determined by searching zebrafish genome (http://www. ensembl.org $/$ Multi/blastview?species $=$ Danio rerio) and PCR. Physical mapping was carried out using the LN54 radiation hybrid panel (20). Primers used for mapping I $\mathrm{f}$ fl $\mathrm{ra}$ amplified the last $197 \mathrm{bp}$ of exon 21 and the first 142bp of the $3^{\prime}$ UTR (forward 5'-CAGGCCTGGCTCTGGATAAGCACTCAG-3' and reverse $5^{\prime}$-TGCCCAAACCGTCCTCCGTCATTCCAA- ${ }^{\prime}{ }^{\prime}$ ). Primers used for mapping I $g$ flrb amplified a 222 bp portion of exon 22 (forward 5'-GATGCGTCGGATGTGTGTCAAGCCACT-3' and reverse 5' - CAGTCAGTGATCCTGTCTGGCGGAAAT-3').

\section{Morpholino knockdown}

MOs were designed according to criteria provided by the commercial supplier (Gene Tools, LLC; Corvallis, OR). Two antisense MOs were designed against distinct sequences in the $5^{\prime}$ UTR of each zebrafish ig f1r. The two ig flra targeting MOs are: igflra MO 1, 5'-TCGCTGTTCCAGATCTCATTCCTAA- $3^{\prime}$; and ig flra MO 2, 5'-TGAAATTGCAGAAAAACGCGAGGCT $-3^{\prime}$. The two $i g f 1 r b$ targeting MOs are: $i g f 1 r b$ MO 1 , 5'-TGTTTGCTAGACCTCATTCGTGTAC-3'; and ig flrb MO 2, 5'AGAAATTAGGGAGAGACACCTCAAC-3'. In addition, we used two gene-specific mis-sense control MOs (igflra Control MO, 5'-TCGgTGTagCAGATCTCtTTCgTAA-3'; and ig flrb Control MO, 5'- TGaaTGCaAGAtCTCATaCCTcTAC3'; small letters indicate nucleotide substitutions).
Construction of the igflra- and igf1rb-GFP reporter plasmids

A $650 \mathrm{bp}$ cDNA fragment corresponding to a portion of the $5^{\prime}$ UTR of the zebrafish igflra gene (including the MO targeting regions) was generated by RT-PCR (forward primer, 5'-TTTTTGTTGGAGGAGAAGCCG-3'; reverse primer, 5'-TTACCATGGTCAACTTGGGGA-3' ${ }^{\prime}$. The amplified DNA fragment was digested with EcoRI and PstI and was then subcloned into the pEGFP-N1 plasmid (Clontech; Palo Alto, CA). Similarly, an $880 \mathrm{bp}$ DNA fragment corresponding to a portion of the $5^{\prime}$ UTR of the zebrafish igflrb gene (including the MO target regions) was generated by RT-PCR (forward primer, 5'-ATCTCGAGAGAACCGCGCTGCTGAGGT-3'; reverse primer: 5'-TAGGATCCTTGCGGAAGACCTCCTGAT-3'). The amplified DNA fragment was digested with BamHI and XhoI andesubcloned into the pEGFP-N1 plasmid. The orientation and accuracy of sequences were verified by DNA sequencing.

\section{Microinjection}

MOs and/or plasmid DNA were injected into 1-2 cell stage embryos as reported (21). In pilot experiments, control and gene-specific MOs were injected at a range of doses. A nominal concentration of $2.5 \mathrm{ng}$ for each of the two igflra MOs (5 ng total MO injected per embryo) and $4 \mathrm{ng}$ for each of the two $i g f 1 r b$ MOs ( $8 \mathrm{ng}$ total per embryo) yielded consistent and reproducible phenotypes. These doses were used for all experimental analysis, except for analysis of spontaneous muscle contractility and motoneuron quantification where the same amount of ifglra MOs and igflrb MOs were injected per embryo (5 ng total MO per embryo). For the GFP reporter assays, $100 \mathrm{pg}$ of plasmid and $2 \mathrm{ng}$ of the indicated MO were injected per embryo.

\section{Western blot}

Twenty five embryos from each treatment group were dechorionated, deyolked, and homogenized in $100 \mu \mathrm{l}$ of RIPA buffer (50 mM Tris-HCl, $150 \mathrm{mM} \mathrm{NaCl,} 2$ mM EGTA, $0.1 \%$ Triton X-100, $\mathrm{pH} 7.5)$ containing $10 \mu \mathrm{g} / \mathrm{ml}$ aprotinin, $10 \mu \mathrm{g} / \mathrm{ml}$ leupeptin, $10 \mu \mathrm{g} / \mathrm{ml}$ pepstatin, $100 \mathrm{mM}$ PMSF, and $0.1 \mathrm{M}$ sodium orthovanadate. The homogenates were briefly centrifuged to pellet cellular debris and the supernatant was retained. Protein levels of each sample were quantified using a protein assay kit (Pierce Biotechnology, Rockford, IL). Equal amounts of protein were analyzed by SDS-PAGE and Western blot as described previously (22). The total Akt Ab and the phospho-Akt Ab (Ser-473 and Thr308) were both used at a 1:1000 dilution.

\section{Whole mount in situ hybridization and antibody staining}

Whole mount in situ hybridization using digoxigenin (DIG)labeled RNA riboprobes and Ab staining were carried out as reported previously (18). Ventricle tissue and skeletal muscle fibers were labeled by F59 staining at 1:10 dilution, hair cells in the otic vesicles were labeled using an anti-Tubulin Ab (1:1000 dilution), and motoneuron axons were labeled by SV2 staining (1:2000 dilution). Microphotographs were taken with a Nikon EC600 fluorescence microscope or acquired by laser scanning confocal microscopy (Model LSM 510, Carl Zeiss, Germany).

\section{Immunocytochemistry}

Cryosections were prepared following $\mathrm{Hu}$ and Easter et al. (23). The sections $(10 \mu \mathrm{m})$ were collected and air-dried at 
room temperature for $2 \mathrm{~h}$ before immunocytochemistry or storage at $-20 \mathrm{C}$. After washing, sections were incubated in PBS at $37 \mathrm{C}$ for $15 \mathrm{~min}$ to remove excess gelatin. Nonspecific binding was blocked by incubation in $5 \%$ goat serum $/ 0.5 \%$ Triton/PBS for $1 \mathrm{~h}$ at room temperature. Muscle tissue staining was performed with a 1:20 dilution of F59. The retinal ganglion cell (RGC) layer was immunostained using a 1:500 dilution of Zn5. Primary antibodies were visualized with a 1:500 dilution of a Cy3-conjugated goat antimouse secondary Ab. Nuclei were counterstained with $50 \mathrm{nM}$ sytox (Molecular Probes, Eugene, OR). Images were acquired as described above.

\section{Body size, heart rate, and motoneuron measurements}

Body length, somite number, and heart rates were measured as reported (21). The caudal primary motoneurons (CaP) located above the yolk sac extension were quantified in $48 \mathrm{hpf}$ embryos after staining with SV2 followed by color detection using a Vectastain avidin-biotin complex detection kit (Vector Labs; Burlingame, CA). Motoneurons were scored as present regardless of length or organization.

\section{Statistics}

Quantitative data are presented as means \pm SE. (SEM). Differences among groups were statistically compared using one-way ANOVA followed with PLSD or Student's $t$ test. Statistical significance was accepted when $p<0.05$.

\section{RESULTS}

\section{Genomic structure and chromosomal locations of zebrafish igflra and igflrb}

The genomic structures of zebrafish igflra and igflrb were determined by searching the zebrafish genome database and PCR. Zebrafish igflra spans $151.5 \mathrm{~kb}$ in the genome. Like the human IGF1R, zebrafish igflra has 21 exons. Zebrafish igflrb spans $156.5 \mathrm{~kb}$ in the genome and has an extra exon (\#22) in its $3^{\prime}$ end (Fig. 1A, Table 1). Comparisons of exon lengths of the two zebrafish igflr genes with the human IGF1R gene indicated a high degree of cross-species conservation (Table 1). We physically mapped igflra and igflrb using the LN54 radiation hybrid mapping panel (20). While igfirb mapped to linkage group (LG 7) as previously reported (24), igflra mapped to zebrafish LG 18 (Fig. $1 B$ ). Further analysis suggested that igflrb and six other zebrafish genes (fb50h01, cox5a, herc1, mfap1, $p 24 b$ and gro1) located on LG 7 have orthologs on human chromosome 15 (Table 2) (20, 25-27). Similarly, igflra and four other zebrafish genes on LG 18 (arl, fa08a06, mef2a, and sema) also have orthologs on human chromosome 15 (Table 2) (20, 25-27). This result supports existing data that human chromosome 15 shares conserved synteny with zebrafish LGs 7 and $18(27,28)$ and suggests a common ancestry for the human and zebrafish IGF1Rs.
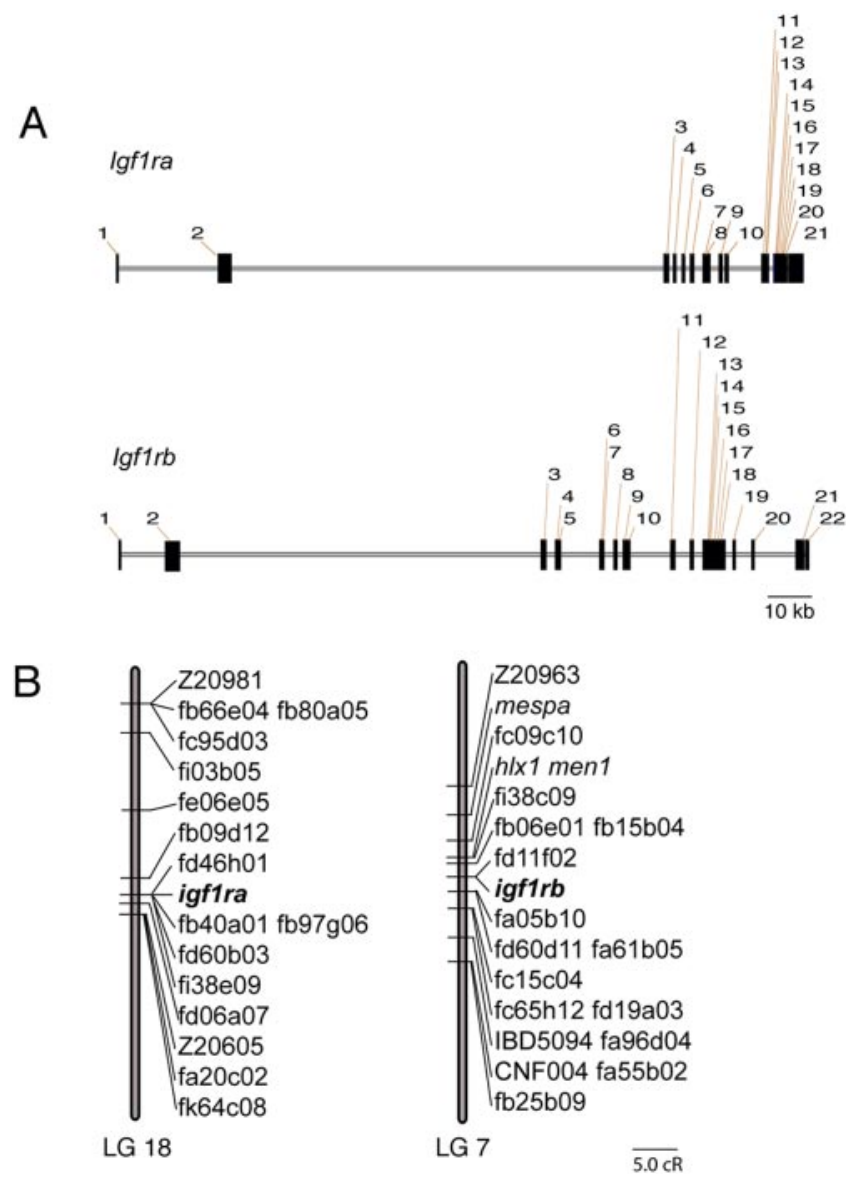

Figure 1. The genomic structure and physical mapping of zebrafish igflra and igflrb. A) A schematic diagram comparing the structures of the zebrafish igflra and igflrb genes. The horizontal lines represent introns, and the vertical black rectangles represent exons. B) Zebrafish ig flra is located on linkage group 18, 2.53 centiRay from marker $f b 09 d 12$, and $i g f 1 r b$ is located on linkage group 7, 4.71 centiRay from marker $f c 09 c 10.1$ centiRay $=148 \mathrm{~kb}$.

\section{Targeted knockdown of zebrafish igflra and igf1rb and inhibition of Igf signaling}

To determine the functions of igflra and igflrb, we ablated each gene product using two independent antisense MOs for each gene. Two gene-specific missense MOs were used as controls. The efficacy and specificity of these MOs in knocking down their respective target gene product were determined using ig $f 1 \mathrm{ra}$ GFP and igflrb-GFP, two reporter genes generated by fusing a portion of the $5^{\prime}$ UTR of each receptor (containing the MO targeting sequences) upstream of GFP. Injection of either the igflra-GFP or igflrb-GFP plasmids into zebrafish embryos resulted in mosaic GFP expression (Fig 2A). As shown in Fig. 2A and 2B, coinjection of the igflra-GFP plasmid with either igflra MO significantly reduced the number of GFP-expressing embryos from $81.40 \pm 3.76 \%$ in embryos injected with control MOs $(n=149)$, to $1.67 \pm 0.58 \%$ in embryos injected with igflra MO $1(n=143)$ and $1.33 \pm 0.58 \%$ in embryos injected with igflra MO $2(n=159)$. In 
TABLE 1. Structural conservation between the human IGF1R and the duplicate zebrafish igf1rs ${ }^{a}$

\begin{tabular}{crcc}
\hline \hline & \multicolumn{3}{c}{ Exon length } \\
\cline { 2 - 4 } Exon number & Human & $\begin{array}{c}\text { Zebrafish } \\
\text { igflra }\end{array}$ & $\begin{array}{c}\text { Zebrafish } \\
\text { igf } f \text { rrb }\end{array}$ \\
\hline & IGF1R & 94 & 82 \\
1 & 1,042 & 564 & 531 \\
2 & 546 & $\mathbf{3 0 4}$ & 298 \\
3 & 313 & 137 & 149 \\
4 & 149 & $\mathbf{1 4 5}$ & $\mathbf{1 4 5}$ \\
5 & 145 & $\mathbf{2 0 9}$ & $\mathbf{2 0 9}$ \\
6 & 215 & $\mathbf{1 2 7}$ & $\mathbf{1 2 7}$ \\
7 & 127 & $\mathbf{2 3 6}$ & 254 \\
8 & 239 & $\mathbf{1 6 8}$ & $\mathbf{1 6 8}$ \\
9 & 168 & $\mathbf{2 0 5}$ & $\mathbf{2 0 5}$ \\
10 & 202 & $\mathbf{2 7 8}$ & $\mathbf{2 8 1}$ \\
11 & 284 & $\mathbf{1 4 3}$ & $\mathbf{1 3 4}$ \\
12 & 137 & $\mathbf{1 6 6}$ & $\mathbf{1 6 6}$ \\
13 & 160 & $\mathbf{1 0 3}$ & $\mathbf{1 0 0}$ \\
14 & 103 & $\mathbf{7 1}$ & $\mathbf{7 1}$ \\
15 & 71 & $\mathbf{2 3 2}$ & 230 \\
16 & 230 & $\mathbf{1 0 6}$ & $\mathbf{1 0 8}$ \\
17 & 111 & $\mathbf{1 6 3}$ & $\mathbf{1 6 0}$ \\
18 & 160 & $\mathbf{1 3 2}$ & $\mathbf{1 3 0}$ \\
19 & 130 & $\mathbf{1 3 2}$ & $\mathbf{1 3 5}$ \\
20 & 135 & 541 & 460 \\
21 & 1,000 & & 237 \\
22 & & & \\
\hline
\end{tabular}

${ }^{a}$ Zebrafish ig f1r exons in boldface indicate \pm 10 bp difference in length compared to the human IGF1R, and exons in italics are identical in length.

contrast, coinjection of ig flrb MO $1+2$ had no such effect $(85.93 \pm 1.99 \%, n=172)$. Similarly, coinjection of the igflrb-GFP plasmid with either igflrb MO significantly reduced the number of GFP-expressing embryos from $86.0 \pm 3.13 \%$ in embryos injected with control MOs $(n=121)$, to $3.3 \pm 0.47 \%$ in embryos injected with igflrb MO $1 \quad(n=94)$ and $4.5 \pm 0.57 \%$ in embryos injected with igflrb MO $2(n=111)$. Coinjection of igflra MO $1+2$ had no such effect $(78.7 \pm 2.72 \%$, $n=94$ ). To show that the endogenous Igflr-mediated signaling was indeed impaired, we analyzed the levels of Akt phosphorylation. Akt is a major downstream effector of the IGF1R in mammals and in zebrafish (29). Western blot analysis indicated a marked reduction in the levels of phosphorylated Akt in the igflra and igfirb MO-injected groups compared to controls. There was a further decrease in the group of embryos injected with a combination of igflra and igflrb MOs. Together, these data indicate that the igflr MOs efficiently and specifically target their respective gene product and disrupt Igflr-mediated signaling.

\section{Igf1ra and Igf1rb are both required for proper embryonic growth, development, and survival}

Embryos injected with control MOs were indistinguishable from wild type embryos (Fig. 3A). In contrast, injection of either igflra MO 1 or igflra MO 2 resulted in embryos that were smaller and developmentally delayed (Fig. 3A). Likewise, injecting either igflrb MO 1 or igflrb MO 2 caused similar growth and developmental retardation (Fig. 3A). Because injecting multiple targeting MOs is known to exert maximal effects (30, 31), we injected both MOs for each receptor. Indeed, these embryos exhibited more severe phenotypes (Fig. 3A) and were used for subsequent analysis. All ig flra and ig flrb MO-injected embryos survived to $48 \mathrm{hpf}$ and $\sim 50 \%$ were alive at $72 \mathrm{hpf}$ but none beyond $96 \mathrm{hpf}$. At $24 \mathrm{hpf}$, the mean body lengths of ig flra MO and igflrb MO-injected embryos were $0.95 \pm 0.03 \mathrm{mM}$ and $1.00 \pm 0.02 \mathrm{mM}$, respectively (Fig. $3 B$ ). These values were significantly smaller compared to that of control MO-injected embryos (1.598 $\pm 0.02 \mathrm{mM})$. Knockdown of either igflra or igflrb significantly reduced somite number, which is a quantitative indicator of the developmental rate in zebrafish before $24 \mathrm{hpf}$ (19). Compared to $29.97 \pm 0.20$ somites in control MO-injected embryos, igflra MO-injected embryos had only $20.14 \pm 0.28$ somites, and igflrb MO-injected embryos had only $19.54 \pm 0.48$ somites (Fig. 3C). According to this criterion, embryos at $24 \mathrm{hpf}$ in igflra and igflrb MO-injected groups were developmentally equivalent to control embryos at $\sim 18 \mathrm{hpf}$. These results indicate that knockdown of either zebrafish igflra or $i g f 1 r b$ resulted in embryonic lethality, growth retardation, and developmental delay.

To determine the effect of ablating both igflr genes simultaneously, we injected a combination of all four targeting MOs. All injected embryos died by $30 \mathrm{hpf}$. At $24 \mathrm{hpf}$, their mean body length was $0.854 \pm 0.02 \mathrm{mM}$, significantly smaller than those of the single knockdown group $(P<0.001)$. Likewise, knockdown of igflra and igflrb together resulted in a further reduction in somite number $(16.02 \pm 0.31)$, which is significantly smaller than those of the single knockdown group $(P<0.001)$. These data indicate that Igflra and Igflrb play overlapping but nonredundant roles in regulating embryonic growth, developmental rate, and survival.

TABLE 2. Comparisons of genes mapped on zebrafish LGs 7 and 18 with those on human chromosome 15

\begin{tabular}{|c|c|c|}
\hline Human & Zebrafish & Zebrafish \\
\hline Chr 15 & LG 18 & LG 7 \\
\hline ALDH6 & & $f b 50 h 0^{20}$ \\
\hline ARL & $a r l^{25}$ & \\
\hline COX5A & & $\operatorname{cox} 5 a^{27}$ \\
\hline GATM & $f a 08 a 0 b^{26}$ & \\
\hline HERC1 & & herc $1^{27}$ \\
\hline IGF1R & $i g f 1 r a^{20,26}$ & $i g f 1 r b^{20,2}$ \\
\hline MEF2A & $m e f 2 a^{26,27}$ & \\
\hline MFAP1 & & $m f a p 1^{27}$ \\
\hline $\mathrm{p} 24 \mathrm{~b}$ & & $p 24 b^{27}$ \\
\hline SEMA2 & $\operatorname{sema} 2^{27}$ & \\
\hline TLE3 & & $\operatorname{gro} 1^{20,27}$ \\
\hline
\end{tabular}



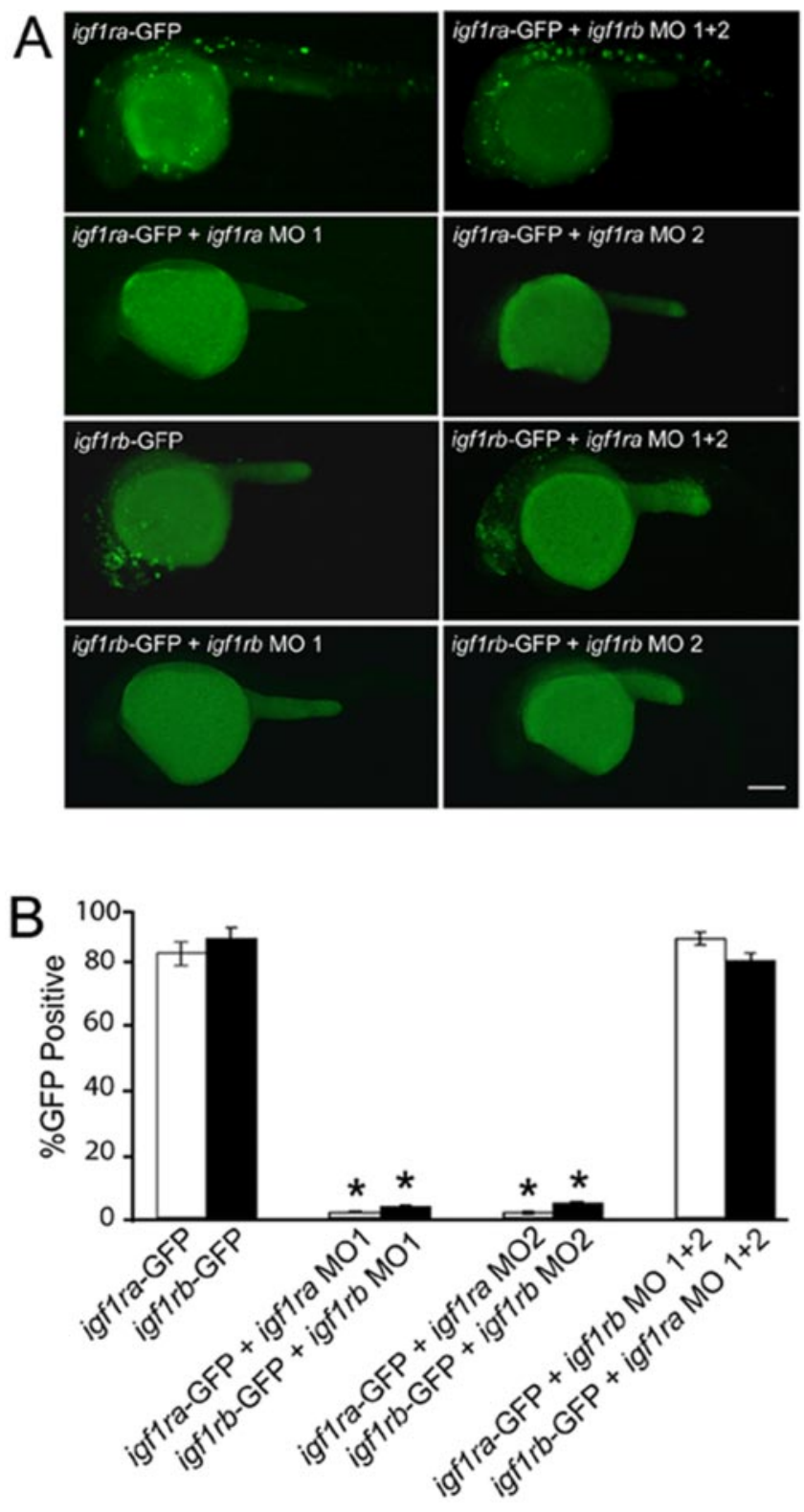

C

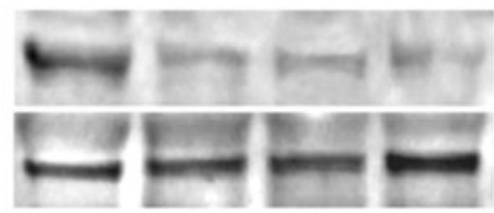

Blot: Phospho-Akt

Blot: Total Akt

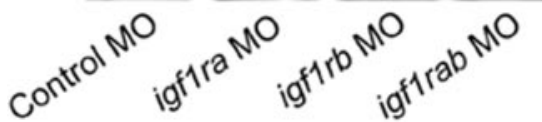

Figure 2. Specific knockdown of igflra and igflrb. A) Fluorescence microscopy images of zebrafish embryos injected with either ig flra-GFP or ig flrb-GFP reporter plasmids, with or without igflra and igflrb MOs. Lateral views are shown with anterior to the left and dorsal up. Each GFP plasmid was injected with or without the indicated MO. The yolk sac is autofluorescent. Scale bar $=250 \mu \mathrm{m}$. B) Quantification of $(A)$. Data are presented as means \pm SEM Results were obtained from three independent microinjection experiments, each with at least 30 embryos per group. $*, P<0.0001$ compared to the control MO-injected group. C) Knockdown of igflra and/or igflrb reduces phosphorylated Akt levels.
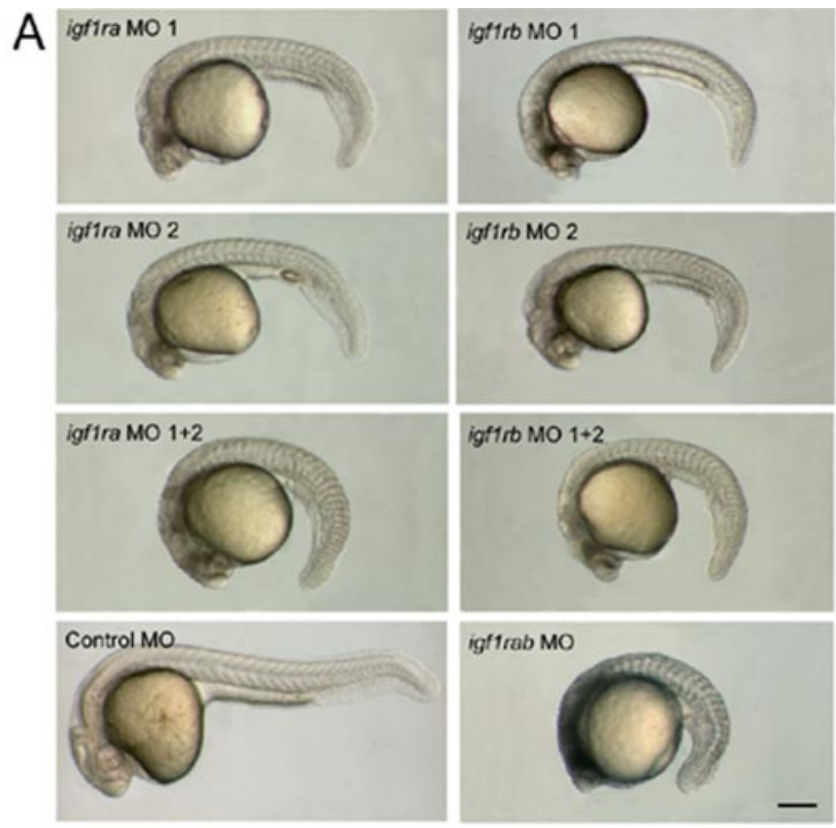

B
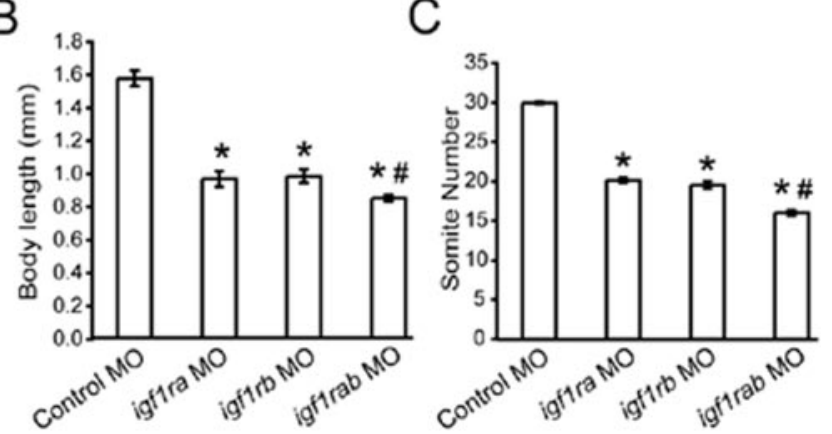

Figure 3. Knockdown of igflra and/or igflrb reduces embryonic growth and developmental rate. A) Morphology of 24 hpf embryos injected with igflra MO 1, igflra MO 2, igflra MO $1+2$, igflrb MO 1, igflrb MO 2, igflrb MO $1+2$, all four igf1r MOs (igflrab MO), or control MOs. Scale bar $=250$ $\mu \mathrm{m}$. B) Body length and $C$ ) somite number of embryos injected with either igflra MOs (igflra MO 1+MO 2), igflrb MOs (igflrb MO 1+2), igflrab MOs (all four igflr MOs), or control MOs. Results are from three independent microinjection experiments, each with 15 embryos per group. $* P<$ 0.0001 compared with the control MO-injected group, and \# $P<0.001$ compared with that of the igflra or igflrb MOinjected group.

\section{Overlapping roles of zebrafish Igf1ra and Igf1rb in eye, inner ear, and heart development}

To investigate the functional roles of the zebrafish Igflrs, we analyzed the impact of knocking down igflra or igflrb on organogenesis of the eye, inner ear, and heart. As shown in Fig. 4A, knockdown of either igflra or $i g f 1 r b$ markedly reduced the expression levels of $r x 1$

Embryos injected with either igf1ra MOs, igf1rb MOs, or igflra MO and igflrb MOs were subjected to Western blot analysis using antibodies for total and phospho-Akt. Similar results were obtained in two other experiments. 

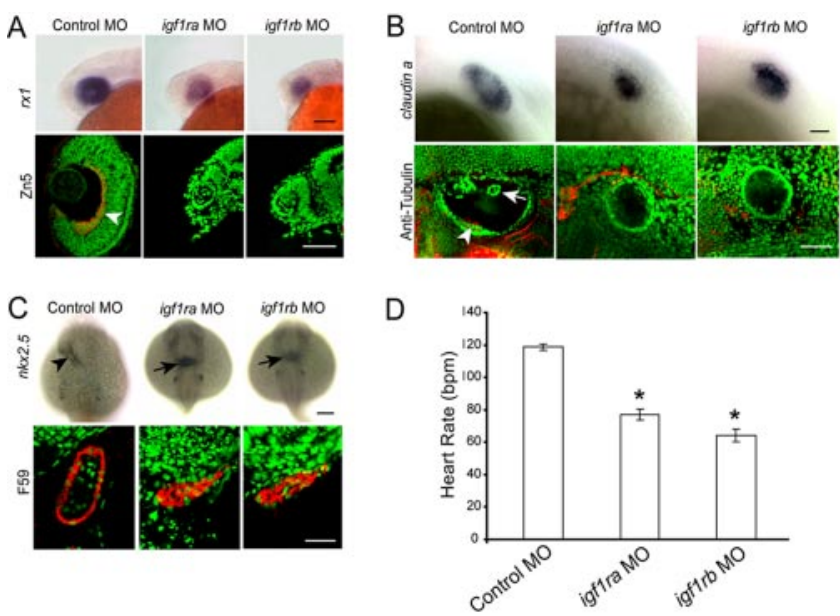

Figure 4. Knockdown of igflra or igflrb causes similar defects in eye, inner ear, and heart development. A) Expression of $r x 1$ mRNA in $24 \mathrm{hpf}$ embryos injected with control MOs, igflra MOs, or igflrb MOs (upper panels). Scale bar $=100 \mu \mathrm{m}$. Differentiated retinal ganglion cells (red, Zn5 staining, arrowhead) in 48 hpf embryos injected with control MOs, igflra MOs, or igflrb MOs. The sections were counter stained with sytox (green, nuclear staining). Dorsal views are shown with anterior up. Scale bar $=50 \mu \mathrm{m}$. Similar results were obtained in two independent microinjection experiments. B) Expression of claudin a mRNA in $24 \mathrm{hpf}$ embryos injected with control MOs, igflra MOs, or igflrb MOs (upper panels). Differentiated hair cells labeled by anti-Tubulin antibody staining (red, arrowhead) in 48 hpf embryos injected with control MOs, igflra MOs, or igflrb MOs. The sections were counter stained with sytox (green, nuclear staining). Epithelium protrusions (arrow), which mark the beginning of semicircular canal formation, were also absent in igflra and igflrb MO-injected embryos. Lateral views are shown with anterior to the left and dorsal up. Scale bars $=50 \mu \mathrm{m}$. Similar results were obtained in two independent microinjection experiments. C) Expression of $n k x 2.5$ mRNA in $24 \mathrm{hpf}$ embryos injected with control MOs, igflra MOs, or ig flrb MO (upper panels). Note the tubular heart in the control MOinjected embryo (arrowhead), compared to the shallow cone structure of the heart tissue in igflra and ig flrb MO-injected embryos (arrows). Dorsal views are shown with anterior up. Scale bar $=100 \mu \mathrm{m}$. Differentiated cardiac cells (red, labeled by F59 staining) in 48 hpf embryos injected with control MOs, igflra MOs, or igflrb MOs. The sections were counter stained with sytox (green, nuclear staining). Ventricles in igflra and ig f1rb MO-injected embryos failed to form distinct chambers. Lateral views are shown with anterior to the left and dorsal up. Scale bar $=50 \mu \mathrm{m}$. Similar results were obtained in three independent experiments. $D$ ) Heart rates (bpm = beat per minute) in $48 \mathrm{hpf}$ embryos injected with control MOs, igflra MOs or igflrb MOs. Results were obtained from three independent microinjection experiments, each with 15 embryos per group. $* P<0.001$.

mRNA, a retina-specific homoebox gene. Neurogenesis in the zebrafish retina begins with the differentiation of the retinal ganglion cells (RGCs) at around $30 \mathrm{hpf}$ (32). By 48 hpf, RGC axons occupy the inner layer of the retina and converge to form a single bundle of axons as they pass out of the retina $(33,34)$. Staining of cryosections of control, igflra, and igflrb MO-injected embryos at 48 hpf with an RGC-specific antibody (Zn5) revealed a general absence of differentiated RGCs in the retina (Fig. 4A). Similarly, there was a notable reduction in the expression domain of claudin $a$, an otic vesicle (inner ear) marker, in igflra and igflrb MOinjected embryos (Fig. $4 B$ ). In developing zebrafish otic vesicles, differentiated sensory hair cells are detectable by $36 \mathrm{hpf}$, and these cells can be labeled by antiTubulin staining (35). Analysis of $48 \mathrm{hpf}$ igflra and igflrb MO-injected embryos revealed a lack of differentiated sensory hair cells (Fig. 4B). Additionally, the protrusions in the epithelium, which mark the beginning of semicircular canal formation, were also absent in igflra and igflrb MO-injected embryos (Fig. 4B). Since knockdown of igflra and igflrb together caused early lethality, these analyses could not be performed in these embryos.

We also detected a delay in heart morphogenesis caused by depleting of Igflra or Igflrb. In situ hybridization analysis of $n k x 2.5$ expression, a heart-specific homeobox gene, indicated that hearts in $24 \mathrm{hpf}$ control MO-injected embryos developed into tubular structures. In contrast, the ventricular tissue in igflra and igflrb MO-injected embryos remained shallow cones, resembling WT embryos at $\sim 18 \mathrm{hpf}$. Immunostaining using F59 revealed a notable reduction in heart size in igflra and igflrb MO-injected embryos (Fig. 4C). The ventricles of igflra and igflrb MO-injected embryos failed to form distinct chambers as observed in control MO-injected embryos. There were also changes in heart function (Fig. 4D). While the mean heart rate of control MO-injected embryos was $120.5 \pm 1.88 \mathrm{bpm}$ (beats per minute), the heart rates of igflra and igflrb MO-injected embryos were significantly lower (79.8 \pm 9.16 bpm and 72.3 $\pm 7.51 \mathrm{bpm}$ ). Taken together, these results indicated that igflra and igflrb play largely similar roles in eye, inner ear, and heart development.

\section{Igf1rb plays a greater role in spontaneous muscle contractility and motoneuron development.}

During the course of the study, we noticed a marked difference in spontaneous contractile activity among the experimental groups. Wild-type zebrafish embryos spontaneously contract their tail muscles at $24 \mathrm{hpf}$ as their motoneuron axons innervate their somitic myotomes (36). By $48 \mathrm{hpf}$, this spontaneous contractility ceases and embryos exhibit rhythmic bouts of swimming. Control MO-injected embryos were indistinguishable from their wild-type siblings, $100 \%$ exhibiting spontaneous muscle contractions at $24 \mathrm{hpf}$ and $0 \%$ at 48 hpf (Fig. 5A). In igflra MO-injected embryos, $69.0 \pm$ $3.07 \%$ of the embryos at $24 \mathrm{hpf}$ and $91.5 \pm 0.54 \%$ at 48 hpf displayed spontaneous contractility, indicating that depletion of igflra delayed or prolong the timing of this behavior. In contrast, few of the igf1rb MO-injected embryos exhibited spontaneous muscle contractility at either $24 \mathrm{hpf}(8.65 \pm 0.60 \%)$ or $48 \mathrm{hpf}(5.5 \pm 0.75 \%)$, suggesting that depletion of igflrb either abolished this behavior or caused a greater delay.

The lack of spontaneous muscle contractility would imply defects in muscle differentiation, motoneuron 

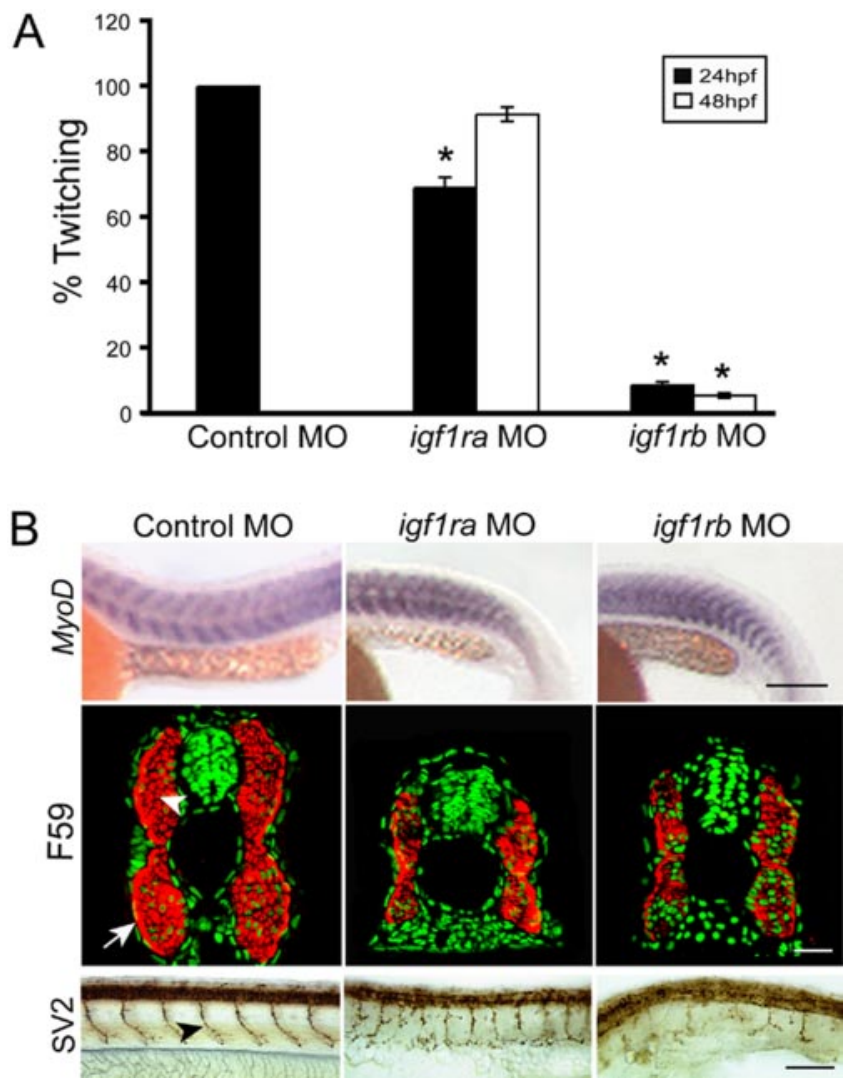

Figure 5. Igflrb plays a greater role in regulating spontaneous muscle contractility and motoneuron formation. A) Percent of embryos exhibiting spontaneous muscle contractility at 24 (filled bar) or $48 \mathrm{hpf}$ (open bar) injected with control MOs, igflra MOs, or igflrb MOs. Results were obtained from three independent microinjection experiments, with 45 embryos per group. $* P<0.0001$ between either igflra or igflrb MO-injected embryos (24 and $48 \mathrm{hpf}$ ) and control MOinjected embryos (24hpf). B) Expression of myoD mRNA in 24 hpf embryos injected with control MOs, igflra MOs, or igflrb MOs. Scale bar $=250 \mu \mathrm{m}$. Differentiated staining slow and fast muscles (labeled by F59 staining, red) of 48 hpf embryos injected with control MOs, igflra MOs, or igflrb MOs. The sections were counter stained with sytox (green, nuclear staining). Scale bar $=20 \mu \mathrm{m}$. Analysis of CaP motoneuron axons in $48 \mathrm{hpf}$ control, igflra, and igflrb MO-injected embryos stained with anti-SV2, a synaptic vesicle protein expressed in motoneuron axons. Lateral views are shown with anterior to the left and dorsal up. Scale bar $=100 \mu \mathrm{m}$. Similar results were obtained in three independent microinjection experiments.

innervation, or both. To determine whether knockdown of igflra or igflrb caused defects in somite formation, in situ hybridization was performed using probes for myoD and myogenin expression. Both igflra and igflrb MO-injected embryos showed robust mRNA expression of myoD (Fig. 5B) and myogenin (data not shown) at $24 \mathrm{hpf}$, indicating no defects in somitogenesis. Immunostaining of $48 \mathrm{hpf}$ embryos using F59 (labeling both fast and slow muscle at this stage) indicated that knockdown of either igflra or igflrb caused a reduction in differentiated slow and fast muscle. The degree of reduction, however, was comparable (Fig. $5 B$ ). Therefore, although muscle differenti- ation was impaired, it is not likely the underlying cause of the difference observed with spontaneous muscle contractility. These results led us to hypothesize alternately that igflrb may perhaps be more important for promoting motoneuron differentiation. To test this idea, $48 \mathrm{hpf}$ old control, igflra, and igfirb MO-injected embryos were stained with an Ab against SV2, which is a synaptic vesicle membrane protein expressed in motoneurons and their axons. As shown in Fig. $5 B$, axons of $\mathrm{CaP}$ motoneurons in control MO-injected embryos clearly innervated the muscle and were well organized, but $\mathrm{CaP}$ axons in igflra and igflrb MO-injected embryos were significantly impaired. In particular, igflrb MO-injected embryos exhibited a reduced number of $\mathrm{CaP}$ motoneuron axons. To quantify this effect, we measured the number of $\mathrm{CaP}$ axons innervating the somites above the yolk sac extension. There were only $4.5 \pm 0.46$ axons detected in igflrb MO-injected embryos. This value was significantly less than the $8.4 \pm 0.8$ axons in igflra MO-injected embryos $(n=8$, $P<0.0001$ ), which was comparable to control MOinjected embryos (9.0 \pm 0.0 axons). These data suggest that while both igflra and igflrb are important for muscle differentiation, Igflrb plays a more specific or greater role in promoting motoneuron innervation.

\section{DISCUSSION}

It is well established that IGF1R-mediated signaling is essential for normal organismal survival, growth, and development in mammals (1-4). The accumulated evidence to date suggests that the major components of the Igf signaling system in teleosts are similar to those in mammals (37). However, there are several key differences. During mammalian fetal development, the mannose 6-phosphate/ type 2 Igf receptor (M6P/ IGF2R) has an important function as a biological sink to prevent tissue overgrowth stimulated by IGF2 (3). Comparative studies indicate that the mannose 6-phosphate receptors of nonmammalian species do not possess the capacity to bind IGF2 with high-affinity (37). In contrast to the presence of a single IGF1R gene in mammals, zebrafish and other teleost species have two genes structurally related to the human $\operatorname{IGF1R}(18,38)$. These two receptors are orthologous to the human $I G F 1 R$ gene phylogenetically, and they both bind to IGFs, but not insulin (18). In this study, we provide evidence that zebrafish Igflra and Igf1rb are encoded by distinct genetic loci believed to have evolved from a common ancestral locus. There is strong syntenic correspondence between the two zebrafish igflrgenes and the human IGF1R gene, suggesting that zebrafish igflra and igflrb originated from a gene duplication event that occurred during teleost evolution. The high degree of conservation in the exon number and length also supports this idea. A previous study has also identified two cDNAs encoding two structurally distinct insulin receptor genes (18). These findings are consistent with the proposal that zebrafish and other ray- 
finned fishes may have experienced an additional gene duplication event during evolution, a theory derived from studies of the Hox gene family in zebrafish and Fugu (39).

The finding that two igflr genes are present in zebrafish raised the interesting question regarding their functional relationship. Gene duplication is thought to be the primary source of new genes (40) and evolution by gene duplication has emerged as a general principal of biological evolution, evident in a number of sequenced genomes ranging from Bacteria to humans (41). Permanent preservation of both duplicates requires divergent functions, but deciphering whether a pair of duplicated genes has evolved divergent functions is often challenging. The zebrafish is uniquely positioned to provide insight into the process of functional gene evolution due to its versatility, amenability to manipulation, and because it possess a large number of duplicated genes. In this study, we explored the power of the zebrafish model and determined the functional relationship of the duplicated zebrafish igflr genes. Knockdown of zebrafish igflra and $i g f 1 \mathrm{rb}$ together resulted in $100 \%$ lethality by $30 \mathrm{hpf}$. These embryos were also significantly smaller in body size, about half that of their wild type siblings. They also had significantly reduced somite number, suggesting delayed temporal development. These phenotypes are consistent with those reported in human patients, $I g \mathrm{flr}$ null mice, and insulin receptor mutant Drosophila (5, 6, $42)$, suggesting that the role of IGF1R-mediated signaling in growth, development, and survival is conserved across a wide range of species. When either igflra or $i g f 1 r b$ was knocked down, the embryos could survive beyond $48 \mathrm{hpf}$, but with greatly increased mortality rates thereafter. Knockdown of igflra or igflrb individually also resulted in similar growth retarded and developmentally delayed phenotypes. Additionally, knockdown of igflra or igflrb resulted in a similar reduction of differentiated RGCs, sensory hair cells in the inner ear, and skeletal muscle. Heart development and growth were also impaired in these embryos. These results suggest that the duplicated zebrafish igflr genes play largely overlapping roles in zebrafish development.

Despite these apparent overlapping functions, Igflra or Igf1rb are not strictly redundant, but appear to play additive roles, because embryos lacking both receptors are more severely growth and developmentally retarded than embryos lacking either receptor alone. It also appears that Igflra and Igf1rb have evolved divergent functions. While knockdown of either igflrb or igflra caused a comparable reduction in muscle differentiation, knockdown of igflrb, but not igflra, caused a failure of embryos to exhibit spontaneous muscle contractility. Further analysis indicated that Igf1rb plays a more specific or greater role in promoting motoneuron innervation of the myotome. Two dominant hypotheses have been proposed regarding the rules governing the functional divergence after gene duplication. The neofunctionalization hypothesis argues that after duplication one daughter gene retains the ancestral function while the other acquires new functions (40). The duplication-degeneration-complementation (DDC) hypothesis asserts that the functions of the ancestral gene are partitioned between the duplicated genes, such that the duplicate genes complement each other by jointly performing the necessary subfunctions of the ancestral gene (43). Our findings concerning the functions of the duplicated zebrafish igflr genes cannot yet be adequately explained by either theory, but are more consistent with recent emerging evidence suggesting that neither subfunctionalization nor neofunctionalization alone can explain the functional evolution of duplicated genes. It has been proposed that a large portion of duplicated genes undergo rapid subfunctionalization followed by prolonged and substantial neofunctionalization (44). Therefore, it is possible that both mechanisms governing duplicated gene evolution have contributed to the current functional state of the two distinct zebrafish igflis.

The mechanism underlying the functional differences in spontaneous muscle contractility and motoneuron maturation/axon extension between zebrafish Igflra and Igflrb is not yet clear. However, there are precedents for two or more isoforms of a growth factor receptor exerting different functions. For example, the two mammalian platelet-derived growth factor (PDGF) receptors (PDGFR), PDGF $\alpha \mathrm{R}$ and PDGF $\beta R$, are thought to be products of a gene duplication event predating the divergence of nonjawed vertebrates and jawed vertebrates $(45,46)$. The $P D G F \alpha R$ and $P D G F \beta R$ genes exhibit different spatiotemporal expression patterns, and display distinct ligand binding properties. While PDGF $\alpha \mathrm{R}$ binds, and is activated by all forms of PDGF (AA, BB and $\mathrm{AB}$ ), PDGF $\beta R$ is activated exclusively by PDGF-BB $(45,46)$. Furthermore, exchanging the intracellular signaling domains of the mouse PDGF $\alpha \mathrm{R}$ and PDGF $\beta R$, caused differences in the abilities of these chimeric receptors to mediate sustained MAP kinase activation, resulting in varying degrees of vascular disease $(45,47)$. Differences in ligand binding affinities, gene expression patterns, and/or signal transduction mechanisms may account for the functional specificity of the two zebrafish igflrgenes. Previous studies have demonstrated that both zebrafish Igflra and Igflrb bind Igfs and that the two zebrafish genes display similar spatial expression patterns during early development, although there are temporal differences in their relative abundance (18). In particular, higher levels of Igflrb were observed in early embryonic stages (18). It was also noted that the two zebrafish Igflrs are only $70 \%$ identical to each other, with the divergent residues spread throughout the molecules, and there are significant differences in the cytoplasmic regions of the two Igflrs. It is possible that these divergent sequences may confer different signaling capacities between the two receptors. Further studies focusing on determining whether the duplicated zebrafish Igflrs possess similar or different cellular distribution patterns and/or signaling 
properties will be needed to elucidate the molecular mechanisms underlying their functions.

This study was supported in part by NSF IBN 0110864 to C.D. We thank Drs. A.W. Wood and J. Zhang for thoughtful comments on earlier drafts of this manuscript. We would also like to thank Drs. M. Ekker, F. Stockdale, R. Kollmar, S. Lyons, P. Raymond, and S.J. Du for kindly providing reagents for this work.

\section{REFERENCES}

1. Le Roith, D., Bondy, C., Yakar, S., Liu, J. L., and Butler, A (2001) The somatomedin hypothesis: 2001. Endocr. Rev. 22, 53-74

2. Jones, J. I., and Clemmons, D. R. (1995) Insulin-like growth factors and their binding proteins: biological actions. Endocr. Rev. 16, 3-34

3. Nakae, J., Kido, Y., and Accili, D. (2001) Distinct and overlapping functions of insulin and IGF-I receptors. Endocr. Rev. 22, $818-835$

4. De Meyts, P., and Whittaker, J. (2002) Structural biology of insulin and IGF1 receptors: implications for drug design. Nat. Rev. Drug Discov. 1, 769-783

5. Abuzzahab, M. J., Schneider, A., Goddard, A., Grigorescu, F., Lautier, C., Keller, E., Kiess, W., Klammt, J., Kratzsch, J., Osgood, D., Pfaffle, R., Raile, K., Seidel, B., Smith, R. J., and Chernausek, S. D. (2003) IGF-I receptor mutations resulting in intrauterine and postnatal growth retardation. N. Engl. J. Med. 349, 2211-2222

6. Kawashima, Y., Kanzaki, S., Yang, F., Kinoshita, T., Hanaki, K., Nagaishi, J., Ohtsuka, Y., Hisatome, I., Ninomoya, H., Nanba, E., Fukushima, T., and Takahashi, S. (2005) Mutation at cleavage site of insulin-like growth factor receptor in a short-stature child born with intrauterine growth retardation. J. Clin. Endocr. Metab. 90, 4679-4687

7. Woods, K. A., Camacho-Hubner, C., Savage, M. O., and Clark, A. J. (1996) Intrauterine growth retardation and postnatal growth failure associated with deletion of the insulin-like growth factor I gene. N. Engl. J. Med. 335, 1363-1367

8. Denley, A., Wang, C. C., McNeil, K. A., Walenkamp, M. J., van Duyvenvoorde, H., Wit, J. M., Wallace, J. C., Norton, R. S., Karperien, M., and Forbes, B. E. (2005) Structural and functional characteristics of the Val44Met insulin-like growth factor I missense mutation: correlation with effects on growth and development. Mol. Endocrinol. 19, 711-721

9. Walenkamp, M. J., Karperien, M., Pereira, A. M., HilhorstHofstee, Y., van Doorn, J., Chen, J. W., Mohan, S., Denley, A., Forbes, B., van Duyvenvoorde, H. A., van Thiel, S. W., Sluimers, C. A., Bax, J. J., de Laat, J. A., Breuning, M. B., Romijn, J. A., and Wit, J. M. (2005) Homozygous and heterozygous expression of a novel insulin-like growth factor-I mutation. J. Clin. Endocrinol. Metab. 90, 2855-2864

10. Baker, J., Liu, J. P., Robertson, E. J., and Efstratiadis, A. (1993) Role of insulin-like growth factors in embryonic and postnatal growth. Cell 75, 73-82

11. Liu, J. P., Baker, J., Perkins, A. S., Robertson, E. J., and Efstratiadis, A. (1993) Mice carrying null mutations of the genes encoding insulin-like growth factor I (Igf-1) and type 1 IGF receptor (Igflr). Cell 75, 59-72

12. Efstratiadis, A. (1998) Genetics of mouse growth. Int. J. Dev. Biol. 42, 955-976

13. Kim, J. J., and Accili, D. (2002) Signalling through IGF-I and insulin receptors: where is the specificity? Growth Horm. IGF Res. 12, 84-90

14. Pera, E. M., Ikeda, A., Eivers, E., and De Robertis, E. M. (2003) Integration of IGF, FGF, and anti-BMP signals via Smad1 phosphorylation in neural induction. Genes Dev. 17, 3023-3028

15. Pera, E. M., Wessely, O., Li, S. Y., and De Robertis, E. M. (2001) Neural and head induction by insulin-like growth factor signals. Dev. Cell 1, 655-665

16. Richard-Parpaillon, L., Heligon, C., Chesnel, F., Boujard, D., and Philpott, A. (2002) The IGF pathway regulates head formation by inhibiting Wnt signaling in Xenopus. Dev. Biol. 244, 407-417
17. Eivers, E., McCarthy, K., Glynn, C., Nolan, C. M., and Byrnes, L. (2004) Insulin-like growth factor (IGF) signalling is required for early dorso-anterior development of the zebrafish embryo. Int. J. Dev. Biol. 48, 1131-1140

18. Maures, T., Chan, S. J., Xu, B., Sun, H., Ding, J., and Duan, C. (2002) Structural, biochemical, and expression analysis of two distinct insulin-like growth factor I receptors and their ligands in zebrafish. Endocrinology 143, 1858-1871

19. Kimmel, C. B., Ballard, W. W., Kimmel, S. R., Ullmann, B., and Schilling, T. F. (1995) Stages of embryonic development of the zebrafish. Dev. Dyn. 203, 253-310

20. Hukriede, N. A., Joly, L., Tsang, M., Miles, J., Tellis, P., Epstein, J. A., Barbazuk, W. B., Li, F. N., Paw, B., Postlethwait, J. H., Hudson, T. J., Zon, L. I., McPherson, J. D., Chevrette, M., Dawid, I. B., Johnson, S. L., and Ekker, M. (1999) Radiation hybrid mapping of the zebrafish genome. Proc. Natl. Acad. Sci. U. S. A. 96, 9745-9750

21. Wood, A. W., Schlueter, P. J., and Duan, C. (2005) Targeted knockdown of insulin-like growth factor binding protein-2 disrupts cardiovascular development in zebrafish embryos. Mol. Endocrinol. 19, 1024-1034

22. Duan, C., Ding, J., Li, Q., Tsai, W., and Pozios, K. (1999) Insulin-like growth factor binding protein 2 is a growth inhibitory protein conserved in zebrafish. Proc. Natl. Acad. Sci. U. S. A. 96, 15274-15279

23. Hu, M., and Easter, S. S. (1999) Retinal neurogenesis: the formation of the initial central patch of postmitotic cells. Dev. Biol. 207, 309-321

24. Ayaso, E., Nolan, C. M., and Byrnes, L. (2002) Zebrafish insulin-like growth factor-I receptor: molecular cloning and developmental expression. Mol. Cell. Endocrinol. 191, 137-148

25. Gates, M. A., Kim, L., Egan, E. S., Cardozo, T., Sirotkin, H. I., Dougan, S. T., Lashkari, D., Abagyan, R., Schier, A. F., and Talbot, W. S. (1999) A genetic linkage map for zebrafish comparative analysis and localization of genes and expressed sequences. Genome Res. 9, 334-347

26. Geisler, R., Rauch, G. J., Baier, H., van Bebber, F., Bross, L., Dekens, M. P., Finger, K., Fricke, C., Gates, M. A., Geiger, H., Geiger-Rudolph, S., et al. (1999) A radiation hybrid map of the zebrafish genome. Nat. Genet. 23, 86-89

27. Woods, I. G., Kelly, P. D., Chu, F., Ngo-Hazelett, P., Yan, Y. L., Huang, H., Postlethwait, J. H., and Talbot, W. S. (2000) A comparative map of the zebrafish genome. Genome Res. 10, 1903-1914

28. Barbazuk, W. B., Korf, I., Kadavi, C., Heyen, J., Tate, S., Wun, E., Bedell, J. A., McPherson, J. D., and Johnson, S. L. (2000) The syntenic relationship of the zebrafish and human genomes. Genome Res. 10, 1351-1358

29. Pozios, K.C., Ding, J., Degger, B., Upton, Z., and Duan, C. (2001) IGFs stimulate zebrafish cell proliferation through activating the MAP kinase and PI3-kinase signaling pathways. Am. J. Physiol. 280, R1230-R1239

30. Ekker, S. C. (2000) Morphants: a new systematic vertebrate functional genomics approach. Yeast 17, 302-306

31. Ekker, S. C., and Larson, J. D. (2001) Morphant technology in model developmental systems. Genesis 30, 89-93

32. Neumann, C. J., and Nuesslein-Volhard, C. (2000) Patterning of the zebrafish retina by a wave of sonic hedgehog activity. Science 289, 2137-2139

33. Easter, S. S., Jr., and Malicki, J. J. (2002) The zebrafish eye: developmental and genetic analysis. Results Probl. Cell Differ. 40, $346-370$

34. Neumann, C. J. (2001) Pattern formation in the zebrafish retina. Semin. Cell Dev. Biol. 12, 485-490

35. Whitfield, T. T., Riley, B. B., Chiang, M. Y., and Phillips, B. (2002) Development of the zebrafish inner ear. Dev. Dyn. 223, 427-458

36. Drapeau, P., Saint-Amant, L., Buss, R. R., Chong, M., McDearmid, J. R., and Brustein, E. (2002) Development of the locomotor network in zebrafish. Prog. Neurobiol. 68, 85-111

37. Wood, A. W., Duan, C., and Bern, H. A. (2005) Insulin-like growth factor signaling in fish. Int. Rev. Cytol. 243, 215-285

38. Chan, S. J., Plisetskaya, E. M., Urbinati, E., Jin, Y., and Steiner, D. F. (1997) Expression of multiple insulin and insulin-like growth factor receptor genes in salmon gill cartilage. Proc. Natl. Acad. Sci. U. S. A. 94, 12446-12451 
39. Amores, A., Force, A., Yan, Y. L., Joly, L., Amemiya, C., Fritz, A., Ho, R. K., Langeland, J., Prince, V., Wang, Y. L., Westerfield, M., Ekker, M., and Postlethwait, J. H. (1998) Zebrafish hox clusters and vertebrate genome evolution. Science 282, 1711-1714

40. Ohno, S. (1970) Evolution by Gene Duplication. Springer-Verlag, New York

41. Zhang, J. (2003) Evolution by gene duplication: an update. Trends Ecol. Evol. 16, 292-298

42. Chen, C., Jack, J., and Garofalo, R. S. (1996) The Drosophila insulin receptor is required for normal growth. Endocrinology 137, 846-856

43. Force, A., Lynch, M., Pickett, F. B., Amores, A., Yan, Y. L., and Postlethwait, J. (1999) Preservation of duplicate genes by complementary, degenerative mutations. Genetics 151, 1531-1545

44. He, X., and Zhang, J. (2005) Rapid subfunctionalization accompanied by prolonged and substantial neofunctionalization in duplicate gene evolution. Genetics 169, 1157-1164
45. Klinghoffer, R. A., Mueting-Nelsen, P. F., Faerman, A., Shani, M., and Soriano, P. (2001) The two PDGF receptors maintain conserved signaling in vivo despite divergent embryological functions. Mol. Cell. 7, 343-354

46. Heldin, C. H., Ostman, A., and Ronnstrand, L. (1998) Signal transduction via platelet-derived growth factor receptors. Biochim. Biophys. Acta 1378, F79-113

47. Klinghoffer, R. A., Hamilton, T. G., Hoch, R., and Soriano, P. (2002) An allelic series at the PDGFalphaR locus indicates unequal contributions of distinct signaling pathways during development. Dev. Cell 2, 103-113

Received for publication November 15, 2005. Accepted for publication January 9, 2006. 